\title{
Perception of telemedicine among medical practitioners in Malaysia during COVID-19
}

\author{
How Kit Thong ', Danny Kit Chung Wong ', Hardip Singh Gendeh ${ }^{2}$, Lokman Saim ${ }^{1,3}$, \\ Primuharsa Putra Bin Sabir Husin Athar ${ }^{1,4}$, Aminuddin Saim ${ }^{1,5 *}$
}

\section{Author Affiliations:}

1. Department of Otorhinolaryngology, Head and Neck Surgery Faculty of Medicine, KPJ Healthcare University College, Negeri Sembilan, Malaysia

2. Department of Otorhinolaryngology Head and Neck Surgery, Faculty of Medicine, Universiti Kebangsaan Malaysia, Kuala Lumpur, Malaysia

3. Department of Otorhinolaryngology, Head and Neck Surgery, KPJ Tawakal Specialist Hospital, Kuala Lumpur, Malaysia

4. Department of Otorhinolaryngology, Head and Neck Surgery, KPJ Seremban Specialist Hospital, Negeri Sembilan, Malaysia

5. Department of Otorhinolaryngology, Head and Neck Surgery, KPJ Ampang Puteri Specialist Hospital, Selangor, Malaysia

\section{ABSTRACT}

The novel Coronavirus Disease 2019 (COVID-19) has brought unprecedented changes in the way conventional health care is delivered. This study examined if clinicians' perceptions regarding telemedicine and its barriers to implementation in Malaysia have changed during this pandemic. A cross-sectional survey was conducted among Malaysian medical doctors of various specialties in four urban healthcare facilities between June 2020 and July 2020. A total of $146(41.7 \%)$ out of 350 responses were obtained. $62 \%$ of doctors reported a reduction greater than $50 \%$ in outpatient visits during the COVID-19 pandemic. The majority of doctors either found telemedicine useful in situations similar to COVID-19 (34.2\%) or that it is essential to their daily practice $(42.5 \%)$. However, only $22 \%$ reported using telemedicine for consultation during the COVID-19 pandemic. $74 \%$ of doctors felt that telemedicine would only benefit up to $30 \%$ of their patient population. Significantly more female doctors $(80 \%)$ felt that telemedicine would benefit their patients compared to male doctors $(45.8 \%)(\mathrm{P}=0.03)$. Physicians $(51.3 \%)$ were more inclined to adopt telemedicine in comparison to surgeons $(32.4 \%)(\mathrm{P}=0.03)$. The majority cited medico-legal issues and consent $(80.6 \%)$, billing and charges $(66.7 \%)$ and insurance reimbursement $(62.5 \%)$, technical difficulties $(62.5 \%)$ as their barrier to the adoption of telemedicine. Female doctors and physicians were more willing to adopt telemedicine when compared to male doctors and surgeons. Although the COVID-19 pandemic appeared to improve the perception, significant barriers should be resolved before many can incorporate it into their practice.
* Corresponding Author: Aminuddin Saim, Professor of Otorhinolaryngology, Senior Consultant, Pediatric Otolaryngologist, Department of Otorhinolaryngology, Head and Neck Surgery, KPJ Ampang Puteri Specialist Hospital, 1, Jalan Mamanda 9, Taman Dato Ahmad Razali, 68000 Ampang, Selangor, Malaysia.

E-mail: aminuddin_saim@yahoo.com

DOI

10.25122/jml-2020-0119

Dates

Received: 28 November 2020

Accepted: 18 May 2021

KEYWORDS: telemedicine, telehealth, GOVID-19, coronavirus.

\section{INTRODUCTION}

The novel Coronavirus Disease 2019 (COVID-19) first emerged as a series of severe pneumonia of unknown etiology in Wuhan, Hubei Province of China on 31 December 2019. The causative agent, known as Severe Acute Respiratory Syndrome Corona Virus 2 (SARS-GoV-2), was isolated on 7 January 2020. Since then, many countries have enforced social isolation or social distancing through 


\section{JOURNAL of MEDICINE and LIFE}

"lockdown" to reduce the spread of disease. In Malaysia, this was termed the "Movement Control order" (MCO) implemented on 18 March 2020 and relaxed on 10 June 2020 [1].

During MCO, Malaysian hospitals had to adapt and comply with new recommendations, resulting in unprecedented changes in the way conventional health care was delivered. These changes involved a suspension of elective surgical procedures, rescheduling non-essential outpatient appointments, and a reduction or redistribution in hospital staff for COVID-19 and hybrid COVID-19 hospitals. Doctors who previously relied on face-to-face encounters were forced to find alternative ways to continue providing care to their patients, thereby creating a renewed interest in telemedicine $[2,3]$.

This was seen in many countries in "lockdown" such as the United Kingdom (UK), United States of America (USA), China, and Australia, where healthcare providers turned to the use of telemedicine, particularly video consultations, as it would limit physical encounters and reduce the risk of infection $[2,3]$. As the pandemic worsened, similar efforts to accelerate telemedicine were seen in Vietnam. Hanoi Medical University Hospital introduced a "digital hospital" project that aimed to encourage telemedicine as a way for both doctor-to-patient and doctor-to-doctor communication. Preliminary results of the effort have revealed the promising role of such implementation to enhance the quality of healthcare service delivery in the digital era [4].

Telemedicine is the practice of medicine using audio, video and data communications, and it can be divided into three categories. The first is patient monitoring at home. The second category consists of real-time interactive or live interactive online applications. These include teleconsultation, videoconferencing, telesurgery, and similar applications. The third category includes store-and-forward applications that use non-interactive technology [5].

During the COVID-19 pandemic, telemedicine has been shown to be beneficial not only with pandemic-related queries but in other disciplines of medicine such as mental health, otorhinolaryngology, urology, ophthalmology, orthopedic surgery and oncology [6-11]. In New York, USA, a reliable health system reported a significant increase in telemedicine usage from 369.1 to 866.8 daily (a 135\% increase) in urgent care cases and from 94.7 to 4209.3 per day (a $4345 \%$ increase) in non-urgent care cases [12]. In the UK, general practitioners have noted 12,000 video consultations per day, which is significantly higher than the previous 300 consultations per month [13].

The increased reliance on telemedicine has inspired several professional organizations, including the European Association of Urology, to create guidelines for the implementation of telemedicine in routine urological practice. In the guidelines, 14 recommendations were introduced to ensure best practices for telemedicine in urology [14]. Optimal implementation will uphold the quality of care received by patients, and the outcomes of patients are of the highest standard.

This study examined if there has been any change in the perceptions of doctors regarding telemedicine, willingness to adopt it, and its barriers to implementation here in Malaysia during this COVID-19 pandemic. The focus was primarily on the second category of telemedicine (i.e., teleconsultation, videoconferencing, or text chat through online applications).

\section{MATERIAL AND METHODS}

\section{Objectives}

The objectives of the study were to:

- Investigate the perception of telemedicine before and during the COVID-19 pandemic;

- Determine the willingness of doctors to adopt telemedicine;

- Explore the barriers to the implementation of telemedicine in Malaysian healthcare.

\section{Study design and ethics approval}

This was a cross-sectional survey in which a self-administered online questionnaire entitled "Is telemedicine relevant in your practice?" was conducted among Malaysian medical practitioners between June 2020 and July 2020. Before the commencement of the study, full ethical approval was obtained from the Research and Innovation Centre of KPJ Healthcare University College. (Approval no: KPJUC/ RMC/EC/2020/283)

\section{Study population}

The questionnaire was distributed to 350 doctors in four private hospitals covering four states, namely KPJ Ampang Puteri Specialist Hospital, KPJ Seremban Specialist Hospital, KPJ Damansara Specialist Hospital and KPJ Penang Specialist Hospital. The participants were from private urban healthcare centers involving consultants from various specialties. Nurses and other allied healthcare professionals were excluded. 


\section{JOURNAL of MEDICINE and LIFE}

\section{Preparation of questionnaire}

The survey was an online questionnaire distributed via e-mail through a Google document format. It was a 16-question self-administered survey.

It was designed and modified based on previously published research articles [15]. A group of two-member experts with experience in the field of telemedicine evaluated the modified questionnaire. The questions were either dichotomous (yes/no) responses or multiple-choice questions.

The questionnaire consists of five domains (Appendix 1):

1. Demographic characteristics (Questions 1-5);

2. Impact of COVID-19 on the healthcare economy (Questions 6-7);

3. Intention to use telemedicine (Questions 8-10);

4. Knowledge and awareness about telemedicine (Questions 11-12);

5. Perceived difficulties in implementing telemedicine (Question 13);

6. Organization readiness (Question 14-16).

\section{Statistical analysis}

Statistical analyses will be performed using the Statistical Package for the Social Sciences (SPSS) software (Version 24.0, IBM Corp., Armonk, NY). Descriptive statistics were used in the form of frequencies and percentages for categorical variables. The Chi-squared test was used to measure the association between some of the variables in the study. A p-value $\leq 0.05$ was considered statistically significant.

\section{RESULTS}

There were 146 respondents out of the 350 invitations sent $(41.7 \%)$. The majority of the respondents were male $(65.75 \%)$, with more than 20 years of experience working as a healthcare professional (64.4\%). The source of knowledge and awareness regarding telemedicine came mainly from social media and news (69.9\%). There were still $4 \%$ of the respondents who reported no knowledge of telemedicine at all (Table 1$)$.

During the COVID-19 pandemic, $62 \%$ of respondents felt that there was a reduction greater than $50 \%$ in outpatient visits and the majority $(63 \%)$ of them felt that the situation would only improve in one to two years.

Almost all (91.8\%) of the respondents were already using an electronic patient record management system at the survey time. Unfortunately, only $22 \%$ of respondents reported using telemedicine for consultations during the COVID-19 pandemic. In regards to what percentage of patients would benefit from telemedicine, the majority $(42.5 \%)$ agreed that less than $10 \%$ would benefit from it, $31.5 \%$ responded between $10-30 \%, 15 \%$ responded between 30 to $50 \%$, and $9.6 \%$ responded above $50 \%$.

When questioned about the future of telemedicine, $34.2 \%$ of doctors found telemedicine useful in situations similar to COVID-19, $42.5 \%$ of doctors found it useful regardless of the occasion and thought it should be integrated as a normal part of clinical practice and $23.3 \%$ of doctors felt that telemedicine was not relevant to their practice. The majority $(67.1 \%)$ agreed that telemedicine was best suited for follow-up cases.

Awareness of the organizational readiness in implementing telemedicine is essential. Unfortunately, 39.7\% had no knowledge of the drug delivery services available at their respective hospital.

In 1997, the Malaysian government implemented the Telemedicine Act as a guideline and proposed a protocol for clinicians to practice telemedicine. Unfortunately, $43.8 \%$ had no knowledge of the act and this proved to be a significant barrier in the implementation of telemedicine in the Malaysian healthcare system.

Table 2 shows the comparison of responses between male and female respondents. $80 \%$ of female respondents answered that at least $10 \%$ or more of their patients would benefit from telemedicine compared to $45.8 \%$ of male respondents $(\mathrm{P}=0.03)$. Other questions about the impact of COVID-19 on healthcare economics, intention and willingness to use telemedicine, knowledge and awareness of telemedicine, and organization readiness showed no statistically significant differences between male and female responses.

Table 3 shows the comparison of responses between surgical specialties and non-surgical specialties. The reduction of outpatient volume during COVID-19 was observed equally in both surgical $(61.8 \%)$ and non-surgical practices $(61.5 \%)$, with the vast majority $(61.6 \%)$ of respondents seeing $50 \%$ or fewer than their typical volume of patients. Significant differences $(\mathrm{P}=0.03)$ were recorded regarding the intention and willingness to use telemedicine, as $51.3 \%$ of non-surgeons agreed that telemedicine was useful and should be part of their daily practice compared to $32.4 \%$ in the group of surgeons. In the group of surgical specialties, $50 \%$ of doctors answered 


\section{JOURNAL of MEDICINE and LIFE}

Table 1. Demographic profile of doctors who responded to the questionnaire.

\begin{tabular}{l|l|l|}
\hline Characteristics & $\mathrm{N}(\mathrm{N}=146)$ & Percentage \\
\hline Gender &
\end{tabular}

\begin{tabular}{|l|l|l|}
\hline ENT & 28 & 19.2 \\
\hline Emergency Medicine & 18 & 12.3 \\
\hline Internal Medicine & 18 & 12.3 \\
\hline Family Medicine & 12 & 8.2 \\
\hline Pediatrics & 12 & 8.2 \\
\hline Obstetrics and Gynecology & 10 & 6.8 \\
\hline Urology & 8 & 5.5 \\
\hline Psychiatry & 6 & 4.1 \\
\hline Orthopedics & 4 & 2.7 \\
\hline General Surgery & 4 & 2.7 \\
\hline Ophthalmology & 4 & 2.7 \\
\hline Dental/Maxillofacial surgery & 4 & 2.7 \\
\hline Anesthesia & 6 & 4.1 \\
\hline Cardiothoracic surgery & 4 & 2.7 \\
\hline Oncology & 2 & 1.4 \\
\hline Plastic surgery & 2 & 1.4 \\
\hline Radiology & 2 & 1.4 \\
\hline Dermatology & 2 & 1.4 \\
\hline
\end{tabular}

\begin{tabular}{|l|c|c|}
\hline \multicolumn{3}{|c|}{ Years of Practice } \\
\hline More than 20 years & 94 & 64.4 \\
\hline $\mathbf{1 0}-\mathbf{2 0}$ years & 36 & 24.7 \\
\hline $\mathbf{5}-\mathbf{1 0}$ years & 16 & 11 \\
\hline Less than $\mathbf{5}$ years & - & - \\
\hline
\end{tabular}

ENT - ear, nose and throat.

\begin{tabular}{|l|c|c|}
\hline Male & 96 & 65.75 \\
\hline Female & 50 & 34.25 \\
\hline & Department of Practice & \\
\hline
\end{tabular}

telemedicine was only useful in situations similar to COVID-19 compared to $20.5 \%$ in the non-surgical group. There were significant differences $(\mathrm{P}=0.01)$ in terms of knowledge and awareness of the 1997 Malaysian act of telemedicine, with 59\% of doctors from non-surgical specialties reporting no knowledge on the existence of the act compared to $26.5 \%$ of surgeons.

Table 4 shows the comparison of responses between different medical disciplines. There were significant differences $(\mathrm{P}=0.01)$ in the reduction of outpatient volume between different disciplines. Internal medicine physicians $(89.9 \%)$, emergency physicians $(66.7 \%)$, pediatricians $(66.7 \%)$ and Ear, Nose and Throat (ENT) surgeons $(64.3 \%)$ reported a reduction greater than $50 \%$ in the outpatient volume. However, doctors in obstetrics and gynecology (60\%) observed a 10 to $20 \%$ reduction in the outpatient volume.

Table 5 shows the comparison of responses between those that adopted telemedicine before and after the COVID-19 pandemic. There were no statistical differences noted in the responses between the two groups. However, doctors that adopted telemedicine after COVID-19 reported a higher acceptance of the technology $(88.9 \%)$. Another notable difference between the two groups was related to the types of patients suitable for the practice of telemedicine. $85.7 \%$ of those that adopted telemedicine earlier felt that the technology is best suited for follow-up patients only. On the contrary, the majority of those who adopted telemedicine after COVID-19 reported that both new and follow-up patients are suitable for telemedicine $(55.6 \%)$.

A variety of different reasons were cited by respondents as barriers against the use of telemedicine, including medico-legal aspect and consent $(80.6 \%)$, billing and charges for such services $(66.7 \%)$, insurance reimbursement/payment for such services (62.5\%), technical difficulties including the setup and availability of technology $(62.5 \%)$, patients willingness to adopt telemedicine $(55.6 \%)$, time consumption and reduction in productivity $(38.9 \%)$ and prescription of a medical certificate $(40.3 \%$ ) (Figure 1$)$.

\section{DISCUSSION}

\section{Interpretation of the main findings}

In this study, $34.2 \%$ of doctors agreed telemedicine was useful in situations similar to the pandemic of COVID-19, and the majority felt that it should be integrated as a normal part of clinical practice $(42.5 \%)$. There was still a minority $(23 \%)$ of doctors who felt that telemedicine was not relevant to their practice. These findings were similar to the study conducted by Ibrahim et al. in 2010, where almost $80 \%$ of doctors were in favor of the idea of remote communication with their patients [16].

Despite the majority $(62 \%)$ of the doctors experiencing a reduction greater than $50 \%$ in outpatient visits during the COVID-19 pandemic, there was no significant increase in doctors practicing telemedicine when compared to before the pandemic. Only a handful of doctors (14\%) practiced telemedicine before the COVID-19 pandemic, and it increased to $12 \%$ after the pandemic began. This was partly due to the negative perception of Malaysian doctors, as the majority $(74 \%)$ felt that telemedicine would only benefit up to $30 \%$ of their patients. The majority of the surgeons $(67.7 \%)$ felt that telemedicine was only essential during a pandemic such as COVID- 19 . This corresponds to a previous study in Malaysia that shows $67.5 \%$ of clinicians were unwilling to accept a reduction in face-to-face consultations [16], probably due to the poor knowledge of doctors in practicing telemedicine and the unpreparedness of the organization of the respective hospital in implementing the system.

Age of the doctors and seniority in practice may be another explanation for the poor acceptance of telemedicine. In this study, the majority of doctors were senior clinicians $(64 \%)$ who have practiced medicine for more than 20 years. A similar study conducted by 


\section{JOURNAL of MEDICINE and LIFE}

Gaggioli et al. in Milan found that senior male doctors were more reluctant to adopt telemedicine for a variety of reasons [17]. This could also explain our findings in a subgroup analysis where female doctors ( $80 \%$ vs. $45.8 \%)$ were more optimistic than their male counterparts. In our study, most female respondents were in the younger age group, with $48 \%$ practicing for less than 20 years. Our findings differed from previous studies, which stated that male doctors were more likely to adopt telemedicine [17, 18].

This study also showed that physicians $(51.3 \%)$ are more willing to adopt telemedicine than doctors from surgical specialties $(32.4 \%)$. Surgical subspecialties are usually a barrier for telemedicine due to their procedural component [19]. Ophthalmologists, for example,

Table 2. Comparison of questionnaire responses between male and female medical doctors.

\begin{tabular}{|c|c|c|c|c|}
\hline \multicolumn{5}{|c|}{ Percentage \% (N) } \\
\hline Questions & Answers & Male $(\mathrm{N}=96)$ & Female $(\mathrm{N}=50)$ & P-Value \\
\hline \multicolumn{5}{|c|}{ Impact of COVID-19 on Healthcare Economics } \\
\hline \multirow{4}{*}{$\begin{array}{l}\text { Estimated reduction in } \\
\text { outpatient visit during } \\
\text { COVID-19 }\end{array}$} & $10-30 \%$ & $4.17(4)$ & $20(10)$ & \multirow{4}{*}{0.0595} \\
\hline & $30-50 \%$ & $33.33(32)$ & $12(6)$ & \\
\hline & More than $50 \%$ & $60.42(58)$ & $64(32)$ & \\
\hline & Not Affected & $2.08(2)$ & $4(2)$ & \\
\hline \multirow{3}{*}{$\begin{array}{l}\text { When will COVID-19 } \\
\text { improve in Malaysia? }\end{array}$} & Next 6 months & $31.25(30)$ & $36(18)$ & \multirow{3}{*}{0.4315} \\
\hline & $1-2$ years & $62.50(60)$ & 64 (32) & \\
\hline & Never & $6.25(6)$ & 0 & \\
\hline
\end{tabular}

Intention and willingness to use telemedicine

\begin{tabular}{|c|c|c|c|c|}
\hline \multirow{3}{*}{$\begin{array}{l}\text { Are you currently } \\
\text { practicing Telemedicine? }\end{array}$} & $\begin{array}{l}\text { Yes, before the COVID-19 } \\
\text { outbreak }\end{array}$ & $8.33(8)$ & $12(6)$ & \multirow{3}{*}{0.2808} \\
\hline & $\begin{array}{l}\text { Yes, after the COVID-19 } \\
\text { outbreak }\end{array}$ & $8.33(8)$ & $20(10)$ & \\
\hline & No & $83.33(80)$ & $68(34)$ & \\
\hline \multirow{3}{*}{$\begin{array}{l}\text { What is the future } \\
\text { of Telemedicine in } \\
\text { Malaysia? }\end{array}$} & $\begin{array}{l}\text { Only useful in situation } \\
\text { similar to COVID-19 }\end{array}$ & $33.33(32)$ & $36(18)$ & \multirow{3}{*}{0.0643} \\
\hline & $\begin{array}{l}\text { Useful and should be part } \\
\text { of my daily practice }\end{array}$ & 35.42 (34) & 36 (18) & \\
\hline & Not relevant to my practice & $31.25(30)$ & $28(14)$ & \\
\hline \multirow{4}{*}{$\begin{array}{l}\text { Percent of patients that } \\
\text { would benefit from } \\
\text { Telemedicine }\end{array}$} & Less than $10 \%$ & $54.17(52)$ & $20(10)$ & \multirow{4}{*}{0.0293} \\
\hline & $10-30 \%$ & $22.92(22)$ & $48(24)$ & \\
\hline & $30-50 \%$ & $14.58(14)$ & $16(8)$ & \\
\hline & More than $50 \%$ & $8.33(8)$ & $16(8)$ & \\
\hline \multicolumn{5}{|c|}{ Knowledge and awareness of Telemedicine } \\
\hline \multirow{3}{*}{$\begin{array}{l}\text { Which group of } \\
\text { patients is suitable for } \\
\text { Telemedicine? }\end{array}$} & New cases & $2.08(2)$ & $4(2)$ & \multirow{3}{*}{0.6245} \\
\hline & Follow-up cases & $70.83(68)$ & $60(30)$ & \\
\hline & Both groups & $27.08(26)$ & $36(18)$ & \\
\hline \multirow{5}{*}{$\begin{array}{l}\text { Where did you learn } \\
\text { about Telemedicine? }\end{array}$} & Not heard of it & $4.17(4)$ & $4(2)$ & \multirow{5}{*}{0.5069} \\
\hline & News or social media & $75.00(72)$ & $60(30)$ & \\
\hline & Hospital Management & $18.75(18)$ & $28(14)$ & \\
\hline & Friends and family & 0 & $4(2)$ & \\
\hline & $\begin{array}{c}\text { Government /Ministry of } \\
\text { Health }\end{array}$ & $2.08(2)$ & $4(2)$ & \\
\hline
\end{tabular}


JOURNAL of MEDICINE and LIFE

Organization Readiness

\begin{tabular}{|l|c|c|c|}
\hline $\begin{array}{l}\text { Do you use IT solutions } \\
\text { for patient record } \\
\text { management? }\end{array}$ & Yes & $89.58(86)$ & $96(48)$ \\
\hline $\begin{array}{l}\text { Does your practice } \\
\text { provide delivery of } \\
\text { prescriptions? }\end{array}$ & Yes & $10.42(10)$ & $4(2)$ \\
\hline & No & $35.42(34)$ & $48(24)$ \\
\hline $\begin{array}{l}\text { 1997 Act of Telemedicine. } \\
\text { Should it be reviewed? }\end{array}$ & Yes & $64.58(62)$ & $52(26)$ \\
\hline & I ho & $52.08(50)$ & 0.3236 \\
\hline
\end{tabular}

Table 3. Comparison of questionnaire responses between surgeons and non-surgeons.

\begin{tabular}{|c|c|c|c|c|}
\hline \multicolumn{5}{|c|}{ PERCENTAGE \% (N) } \\
\hline Questions & Answers & $\begin{array}{l}\text { Non-surgical specialties } \\
\qquad(\mathrm{N}=78)\end{array}$ & $\begin{array}{l}\text { Surgical specialties } \\
\qquad(N=68)\end{array}$ & P-Value \\
\hline \multicolumn{5}{|c|}{ Impact of COVID-19 on Healthcare Economics } \\
\hline \multirow{4}{*}{$\begin{array}{l}\text { Estimated reduction in } \\
\text { outpatient visits during } \\
\text { COVID-19 }\end{array}$} & $10-30 \%$ & $10.26(8)$ & $8.82(6)$ & \multirow{4}{*}{0.9968} \\
\hline & $30-50 \%$ & $25.64(20)$ & $26.47(18)$ & \\
\hline & More than $50 \%$ & $61.54(48)$ & $61.76(42)$ & \\
\hline & Not Affected & $2.56(2)$ & $2.94(2)$ & \\
\hline \multirow{3}{*}{$\begin{array}{l}\text { When will COVID-19 } \\
\text { improve in Malaysia? }\end{array}$} & Next 6 months & $38.46(30)$ & $26.47(18)$ & \multirow{3}{*}{0.4527} \\
\hline & $1-2$ years & $56.41(44)$ & $70.59(48)$ & \\
\hline & Never & $5.13(4)$ & $2.94(2)$ & \\
\hline \multicolumn{5}{|c|}{ Intention and willingness to use telemedicine } \\
\hline \multirow{3}{*}{$\begin{array}{l}\text { Are you currently } \\
\text { practicing Telemedicine? }\end{array}$} & $\begin{array}{c}\text { Yes, before the COVID-19 } \\
\text { outbreak }\end{array}$ & $10.26(8)$ & $8.82(6)$ & \multirow{3}{*}{0.8387} \\
\hline & $\begin{array}{l}\text { Yes, after the COVID-19 } \\
\text { outbreak }\end{array}$ & $10.26(8)$ & $14.71(10)$ & \\
\hline & No & $79.49(62)$ & $76.47(52)$ & \\
\hline \multirow{3}{*}{$\begin{array}{l}\text { What is the future } \\
\text { of Telemedicine in } \\
\text { Malaysia? }\end{array}$} & $\begin{array}{l}\text { Only useful in situation } \\
\text { similar to COVID-19 }\end{array}$ & $20.51(16)$ & $50.00(34)$ & \multirow{3}{*}{0.03} \\
\hline & $\begin{array}{l}\text { Useful and should be part } \\
\text { of my daily practice }\end{array}$ & $51.28(40)$ & 32.35 (22) & \\
\hline & $\begin{array}{l}\text { Not relevant to my } \\
\text { practice }\end{array}$ & $28.21(22)$ & $17.65(12)$ & \\
\hline \multirow{4}{*}{$\begin{array}{l}\text { Percent of patients that } \\
\text { would benefit from } \\
\text { Telemedicine }\end{array}$} & Less than $10 \%$ & $38.46(30)$ & $47.06(32)$ & \multirow{4}{*}{0.1144} \\
\hline & $10-30 \%$ & $41.03(32)$ & $23.53(16)$ & \\
\hline & $30-50 \%$ & $7.69(6)$ & $23.53(16)$ & \\
\hline & More than $50 \%$ & $12.82(10)$ & $5.88(4)$ & \\
\hline
\end{tabular}


JOURNAL of MEDICINE and LIFE

\begin{tabular}{|c|c|c|c|c|}
\hline \multicolumn{5}{|c|}{ Knowledge and awareness of Telemedicine } \\
\hline \multirow{3}{*}{$\begin{array}{l}\text { Which group of } \\
\text { patients is suitable for } \\
\text { Telemedicine? }\end{array}$} & New cases & $5.13(4)$ & 0 & \multirow{3}{*}{0.3966} \\
\hline & Follow-up cases & $66.67(52)$ & $67.65(46)$ & \\
\hline & Both groups & $28.21(22)$ & $32.35(22)$ & \\
\hline \multirow{5}{*}{$\begin{array}{l}\text { Where did you learn } \\
\text { about Telemedicine? }\end{array}$} & Not heard of it & $7.69(6)$ & 0 & \multirow{5}{*}{0.1266} \\
\hline & News or social media & $58.97(46)$ & $82.35(56)$ & \\
\hline & Hospital Management & $25.64(20)$ & $17.65(12)$ & \\
\hline & Friends and family & $2.56(2)$ & 0 & \\
\hline & $\begin{array}{c}\text { Government /Ministry of } \\
\text { Health }\end{array}$ & $5.13(4)$ & 0 & \\
\hline \multicolumn{5}{|c|}{ Organization Readiness } \\
\hline \multirow{2}{*}{$\begin{array}{l}\text { Do you use IT solutions } \\
\text { for patient record } \\
\text { management? }\end{array}$} & Yes & $92.31(72)$ & $91.18(62)$ & \multirow[t]{2}{*}{$1(0.5948)$} \\
\hline & No & $7.69(6)$ & $8.82(6)$ & \\
\hline \multirow{2}{*}{$\begin{array}{l}\text { Does your practice } \\
\text { provide delivery of } \\
\text { prescriptions? }\end{array}$} & Yes & $48.72(38)$ & $9.41(20)$ & \multirow{2}{*}{0.1018} \\
\hline & No & $51.28(40)$ & $70.59(48)$ & \\
\hline \multirow{3}{*}{$\begin{array}{l}1997 \text { Act of Telemedicine. } \\
\text { Should it be reviewed? }\end{array}$} & Yes & $41.03(32)$ & $70.59(48)$ & \multirow{3}{*}{0.0148} \\
\hline & No & 0 & $2.94(2)$ & \\
\hline & $\begin{array}{l}\text { I have no knowledge of } \\
\text { the Act }\end{array}$ & $58.97(46)$ & $26.47(18)$ & \\
\hline
\end{tabular}

Table 4. Comparison of questionnaire responses between doctors from various disciplines.

\begin{tabular}{|c|c|c|c|c|c|c|c|c|c|c|}
\hline \multicolumn{11}{|c|}{ PERCENTAGE \% (N) } \\
\hline Questions & Answers & $\begin{array}{l}\text { ENT } \\
(n=28)\end{array}$ & $\begin{array}{c}\text { Emergency } \\
\text { Medicine } \\
(n=18)\end{array}$ & $\begin{array}{l}\text { Internal } \\
\text { Medicine } \\
(n=18)\end{array}$ & $\begin{array}{l}\text { Family } \\
\text { Medicine } \\
(n=12)\end{array}$ & $\begin{array}{l}\text { Pediatrics } \\
\quad(n=12)\end{array}$ & $\begin{array}{c}\text { O\&G } \\
(n=10)\end{array}$ & $\begin{array}{l}\text { Others* } \\
(n=48)\end{array}$ & $\begin{array}{c}\text { Total } \\
(n=146)\end{array}$ & P-Value \\
\hline \multicolumn{11}{|c|}{ Impact of COVID-19 on Healthcare Economics } \\
\hline \multirow{4}{*}{$\begin{array}{l}\text { reduction in } \\
\text { outpatient } \\
\text { visit during } \\
\text { COVID-19 }\end{array}$} & $10-30 \%$ & - & - & - & $33.33(4)$ & $16.7(2)$ & $60(6)$ & $4.2(2)$ & $9.6(14)$ & \multirow{4}{*}{0.0122} \\
\hline & $30-50 \%$ & $35.7(10)$ & $33.3(6)$ & $11.1(2)$ & $16.67(2)$ & $16.7(2)$ & - & $33.3(16)$ & $26.0(38)$ & \\
\hline & $\begin{array}{l}\text { More than } \\
50 \%\end{array}$ & 64.3(18) & $66.7(12)$ & $88.9(16)$ & $50.00(6)$ & $66.7(8)$ & $20(2)$ & $58.3(28)$ & $61.6(90)$ & \\
\hline & Not Affected & - & - & - & - & - & $20(2)$ & $4.2(2)$ & $2.7(4)$ & \\
\hline \multirow{3}{*}{$\begin{array}{l}\text { When will } \\
\text { COVID-19 } \\
\text { improve in } \\
\text { Malaysia? }\end{array}$} & $\begin{array}{l}\text { Next } 6 \\
\text { months }\end{array}$ & $35.7(10)$ & $33.3(6)$ & 44.4(8) & $50.00(6)$ & $50(6)$ & $20(2)$ & 20.8(10) & $32.9(48)$ & \multirow{3}{*}{0.7946} \\
\hline & $1-2$ years & 64.3(18) & 55.6(10) & 44.4(8) & $50.00(6)$ & 50(6) & $80(8)$ & $75(36)$ & $63.0(92)$ & \\
\hline & Never & - & $11.1(2)$ & $11.1(2)$ & - & - & - & $4.2(2)$ & 4.1(6) & \\
\hline
\end{tabular}




\section{JOURNAL of MEDICINE and LIFE}

\begin{tabular}{|c|c|c|c|c|c|c|c|c|c|c|}
\hline \multicolumn{11}{|c|}{ Intention and willingness to use telemedicine } \\
\hline \multirow{3}{*}{$\begin{array}{l}\text { Are you } \\
\text { currently } \\
\text { practicing } \\
\text { Telemedicine? }\end{array}$} & $\begin{array}{l}\text { Yes, before } \\
\text { the COVID-19 } \\
\text { outbreak }\end{array}$ & 7.1(2) & - & - & - & 33.3(4) & $20(2)$ & $12.5(6)$ & $9.6(14)$ & \multirow{3}{*}{0.6104} \\
\hline & $\begin{array}{l}\text { Yes, after } \\
\text { the COVID-19 } \\
\text { outbreak }\end{array}$ & $7.1(2)$ & $22.2(4)$ & $11.1(2)$ & $16.67(2)$ & - & - & $16.7(8)$ & $12.3(18)$ & \\
\hline & No & $85.7(12)$ & $77.8(14)$ & $88.9(16)$ & $83.33(10)$ & $66.7(8)$ & $80(8)$ & $70.8(34)$ & 78.1(114) & \\
\hline \multirow{3}{*}{$\begin{array}{l}\text { What is the } \\
\text { future of } \\
\text { Telemedicine } \\
\text { in Malaysia? }\end{array}$} & $\begin{array}{l}\text { Only useful } \\
\text { in situation } \\
\text { similar to } \\
\text { COVID-19 }\end{array}$ & $50(14)$ & - & $22.2(4)$ & $16.67(2)$ & $50(6)$ & $40(4)$ & $41.7(20)$ & $34.2(50)$ & \multirow{3}{*}{0.0607} \\
\hline & $\begin{array}{l}\text { Useful and } \\
\text { should be } \\
\text { part of my } \\
\text { daily practice }\end{array}$ & $42.9(12)$ & $88.9(16)$ & $55.56(10)$ & 33.33(4) & $50(6)$ & $20(2)$ & $25(12)$ & $42.5(62)$ & \\
\hline & $\begin{array}{l}\text { Not relevant } \\
\text { to my } \\
\text { practice }\end{array}$ & 7.1(2) & $11.1(2)$ & $22.2(2)$ & $50.00(6)$ & - & $40(4)$ & 33.3(16) & 23.3(34) & \\
\hline \multirow{4}{*}{$\begin{array}{l}\text { Percent of } \\
\text { patients } \\
\text { that would } \\
\text { benefit from } \\
\text { Telemedicine }\end{array}$} & $\begin{array}{l}\text { Less than } \\
10 \%\end{array}$ & $50(14)$ & $44.4(8)$ & $33.3(6)$ & 33.33(4) & - & $40(4)$ & $54.2(26)$ & $42.5(62)$ & \multirow{4}{*}{0.4477} \\
\hline & $10-30 \%$ & $21.4(6)$ & $22.2(4)$ & $55.6(10)$ & $33.33(4)$ & $83.3(10)$ & $20(2)$ & $20.8(10)$ & $31.5(46)$ & \\
\hline & $30-50 \%$ & $14.3(4)$ & $11.1(2)$ & $11.1(2)$ & $16.67(2)$ & - & $40(4)$ & $20.8(10)$ & $16.5(24)$ & \\
\hline & $\begin{array}{c}\text { More than } \\
50 \%\end{array}$ & $14.3(4)$ & $22.2(4)$ & - & $16.67(2)$ & $16.7(2)$ & - & $4.2(2)$ & $9.59(14)$ & \\
\hline \multicolumn{11}{|c|}{ Knowledge and awareness of Telemedicine } \\
\hline \multirow{3}{*}{$\begin{array}{l}\text { Which group } \\
\text { of patients is } \\
\text { suitable for } \\
\text { Telemedicine? }\end{array}$} & New cases & - & $11.1(2)$ & - & - & - & - & $4.2(2)$ & $2.7(4)$ & \multirow{3}{*}{0.8706} \\
\hline & $\begin{array}{l}\text { Follow-up } \\
\text { cases }\end{array}$ & $71.4(20)$ & $66.7(12)$ & $55.56(10)$ & $83.33(10)$ & $83.3(10)$ & $80(8)$ & $58.3(28)$ & $67.1(98)$ & \\
\hline & Both groups & $28.6(8)$ & $22.2(4)$ & $44.44(8)$ & $16.67(2)$ & $16.7(2)$ & $20(2)$ & $37.5(18)$ & $30.1(44)$ & \\
\hline \multirow{5}{*}{$\begin{array}{l}\text { Where did you } \\
\text { learn about } \\
\text { Telemedicine? }\end{array}$} & $\begin{array}{l}\text { Not heard } \\
\text { of it }\end{array}$ & - & $22.2(4)$ & $11,1(2)$ & - & - & - & - & $4.1(6)$ & \multirow{5}{*}{0.1389} \\
\hline & $\begin{array}{c}\text { News or } \\
\text { social media }\end{array}$ & $85.7(24)$ & 77.8(14) & $44.4(8)$ & $66.67(8)$ & $50(6)$ & $60(6)$ & $75.00(36)$ & $69.9(102)$ & \\
\hline & $\begin{array}{c}\text { Hospital } \\
\text { Management }\end{array}$ & $14.3(4)$ & - & $33.3(6)$ & $33.33(4)$ & $33.3(4)$ & $40(4)$ & $20.83(10)$ & $21.9(32)$ & \\
\hline & $\begin{array}{l}\text { Friends and } \\
\text { family }\end{array}$ & - & - & - & - & $16.7(2)$ & - & - & $1.4(2)$ & \\
\hline & $\begin{array}{l}\text { Government } \\
\text { /Ministry of } \\
\text { Health }\end{array}$ & - & - & 11.1(2) & - & - & - & $4.17(2)$ & $2.7(4)$ & \\
\hline \multicolumn{11}{|c|}{ Organization Readiness } \\
\hline \multirow{2}{*}{$\begin{array}{l}\text { Do you use IT } \\
\text { solutions for } \\
\text { patient record } \\
\text { management? }\end{array}$} & Yes & $85.7(24)$ & $100(18)$ & $88.9(16)$ & $66.67(8)$ & $100(12)$ & $80(8)$ & $100(48)$ & $91.8(134)$ & \multirow[b]{2}{*}{0.116} \\
\hline & No & $14.3(4)$ & - & 11.1(2) & 33.33(4) & - & $20(2)$ & - & $8.2(12)$ & \\
\hline \multirow{2}{*}{$\begin{array}{l}\text { Does your } \\
\text { practice } \\
\text { provide } \\
\text { delivery of } \\
\text { prescriptions? }\end{array}$} & Yes & $35.7(10)$ & $44.4(8)$ & $55.6(10)$ & $33.33(4)$ & $33.3(4)$ & $20(2)$ & $41.7(20)$ & $39.7(58)$ & \multirow[b]{2}{*}{0.903} \\
\hline & No & 64.3(18) & $55.6(10)$ & $44.4(8)$ & $66.67(8)$ & $66.7(8)$ & 80(8) & $58.3(28)$ & 60.3(88) & \\
\hline
\end{tabular}




\section{JOURNAL of MEDICINE and LIFE}

\begin{tabular}{|l|c|c|c|c|c|c|c|c|c|}
\hline & Yes & $71.4(20)$ & $44.4(8)$ & $44.4(8)$ & $50.00(6)$ & $50(6)$ & $60(6)$ & $54.2(23)$ & $54.8(80)$ \\
\hline $\begin{array}{l}\text { 1997 Act of } \\
\text { Telemedicine. }\end{array}$ & No & $7.1(2)$ & - & - & - & - & - & - & $1.4(2)$ \\
\hline $\begin{array}{l}\text { Should It be } \\
\text { reviewed? }\end{array}$ & $\begin{array}{l}\text { I have no } \\
\text { knowledge } \\
\text { of the Act }\end{array}$ & $21.4(6)$ & $55.6(10)$ & $55.6(10)$ & $50.00(6)$ & $50(6)$ & $40(4)$ & $45.8(22)$ & $43.8(64)$ \\
\hline
\end{tabular}

O\&G - obstetrics and gynecology. * Includes responses from the following disciplines: urology, psychiatry, orthopedics, general surgery, ophthalmology, dental/maxillofacial surgery, anesthesia, cardiothoracic surgery, oncology, plastic surgery, radiology and dermatology.

Table 5. Comparison of questionnaire responses between doctors that adopted telemedicine before and after the COVID-19 pandemic.

\begin{tabular}{|c|c|c|c|c|}
\hline \multicolumn{5}{|c|}{ PERCENTAGE \% (N) } \\
\hline Questions & Answers & $\begin{array}{l}\text { Practicing Telemedicine } \\
\text { before COVID-19 ( } N=14)\end{array}$ & $\begin{array}{l}\text { Practicing telemedicine } \\
\text { after COVID-19 }(\mathrm{N}=18)\end{array}$ & P-Value \\
\hline \multicolumn{5}{|c|}{ Impact of Covid on Healthcare Economics } \\
\hline \multirow{4}{*}{$\begin{array}{l}\text { Estimated reduction in } \\
\text { outpatient visit during } \\
\text { COVID-19 }\end{array}$} & $10-30 \%$ & $14.3(2)$ & - & \multirow{4}{*}{0.1913} \\
\hline & $30-50 \%$ & $14.3(2)$ & - & \\
\hline & More than $50 \%$ & $57.1(8)$ & $100(18)$ & \\
\hline & Not Affected & $14.3(2)$ & - & \\
\hline \multirow{3}{*}{$\begin{array}{l}\text { When will COVID-19 } \\
\text { improve in Malaysia? }\end{array}$} & Next 6 months & - & $55.6(10)$ & \multirow{3}{*}{0.9494} \\
\hline & $1-2$ years & $42.9(6)$ & $44.4(8)$ & \\
\hline & Never & $57.1(8)$ & - & \\
\hline
\end{tabular}

Intention and willingness to use telemedicine

\begin{tabular}{|c|c|c|c|c|}
\hline \multirow{3}{*}{$\begin{array}{l}\text { What is the future } \\
\text { of Telemedicine in } \\
\text { Malaysia? }\end{array}$} & $\begin{array}{l}\text { Only useful in situation } \\
\text { similar to COVID-19 }\end{array}$ & $42.9(6)$ & - & \multirow{3}{*}{0.0756} \\
\hline & $\begin{array}{l}\text { Useful and should be part } \\
\text { of my daily practice }\end{array}$ & $57.1(8)$ & $88.9(16)$ & \\
\hline & $\begin{array}{l}\text { Not relevant to my } \\
\text { practice }\end{array}$ & - & $11.1(2)$ & \\
\hline \multirow{4}{*}{$\begin{array}{l}\text { Percent of patients that } \\
\text { would benefit from } \\
\text { Telemedicine }\end{array}$} & Less than $10 \%$ & $28.6(4)$ & $33.3(6)$ & \multirow{4}{*}{0.5467} \\
\hline & $10-30 \%$ & $57.1(8)$ & $33.3(6)$ & \\
\hline & $30-50 \%$ & - & $22.2(4)$ & \\
\hline & More than $50 \%$ & $14.3(2)$ & $11.1(2)$ & \\
\hline \multicolumn{5}{|c|}{ Knowledge and awareness of Telemedicine } \\
\hline \multirow{3}{*}{$\begin{array}{l}\text { Which group of } \\
\text { patients is suitable for } \\
\text { Telemedicine? }\end{array}$} & New cases & - & $11.1(2)$ & \multirow{3}{*}{0.1061} \\
\hline & Follow-up cases & $85.7(12)$ & $33.3(6)$ & \\
\hline & Both groups & $14.3(2)$ & $55.6(10)$ & \\
\hline \multirow{5}{*}{$\begin{array}{l}\text { Where did you learn } \\
\text { about Telemedicine? }\end{array}$} & Not heard of it & - & - & \multirow{5}{*}{0.8385} \\
\hline & News or social media & $71.4(10)$ & $66.7(12)$ & \\
\hline & Hospital Management & $28.6(4)$ & $33.3(6)$ & \\
\hline & Friends and family & - & - & \\
\hline & $\begin{array}{c}\text { Government /Ministry of } \\
\text { Health }\end{array}$ & - & - & \\
\hline
\end{tabular}




\section{JOURNAL of MEDICINE and LIFE}

\begin{tabular}{|l|c|c|c|}
\hline \multicolumn{3}{|c|}{ Organization Readiness } \\
\hline $\begin{array}{l}\text { Do you use IT solutions } \\
\text { for patient record } \\
\text { management? }\end{array}$ & Yes & $100(14)$ & $100(18)$ \\
\hline $\begin{array}{l}\text { Does your practice } \\
\text { provide delivery of } \\
\text { prescriptions? }\end{array}$ & Yes & - & - \\
\hline \\
\hline $\begin{array}{l}\text { 1997 Act of Telemedicine. } \\
\text { Should It be reviewed? }\end{array}$ & No & $57.1(8)$ & $33.3(6)$ \\
\hline
\end{tabular}

may find that telemedicine is limiting their patients' eye physical examination with an ophthalmoscope or slit lamp that would be required to reach a diagnosis or progress of the disease. Unfortunately, this is not valid in all surgical specialties. Telemedicine is still beneficial, especially during the preoperative and postoperative assessment, thus minimizing the attendance of patients to the hospital, which has a significant impact on the cost of patient care [20]. For example, there was increasing concern about the safety of various endoscopic and laparoscopic procedures during the COVID-19 pandemic in general surgery and colorectal surgery. There appears to be a potential of virus spread with the utilization of laparoscopy, mainly due to aerosolization of bodily fluids and vapor formed by heat-generating cautery devices [21,22]. Various studies have been published to encourage a conservative approach in managing such cases, with endoscopy and proctological procedures performed selectively [23]. Telemedicine has been suggested as a tool for consultation and screening; only those who are deemed not deferrable are attended physically in the hospital [23].

Besides the role in patient teleconsultation, telemedicine is also playing an increasingly important role as a tool to obtain clinical guidelines and communications among team members. A survey done by Benítez et al. concluded that social media and video conferences were the most popular options utilized during the COVID-19 pandemic for such purpose while maintaining social distancing [24].

Another notable mention is the role of telemedicine in the field of psychiatry and mental health. Among the various impacts of COVID-19, fear of infection and uncertainty about the disease can precipitate various psychiatric disorders; those with predisposing mental illness may experience more worry, anxiety, and suicidal ideation and develop other mental illnesses in comparison to healthy controls [25]. Telepsychiatry and smartphone-based cognitive therapy has been demonstrated to be an effective option where psychiatric patients tend to overestimate the risk of contracting COVID-19 [26].

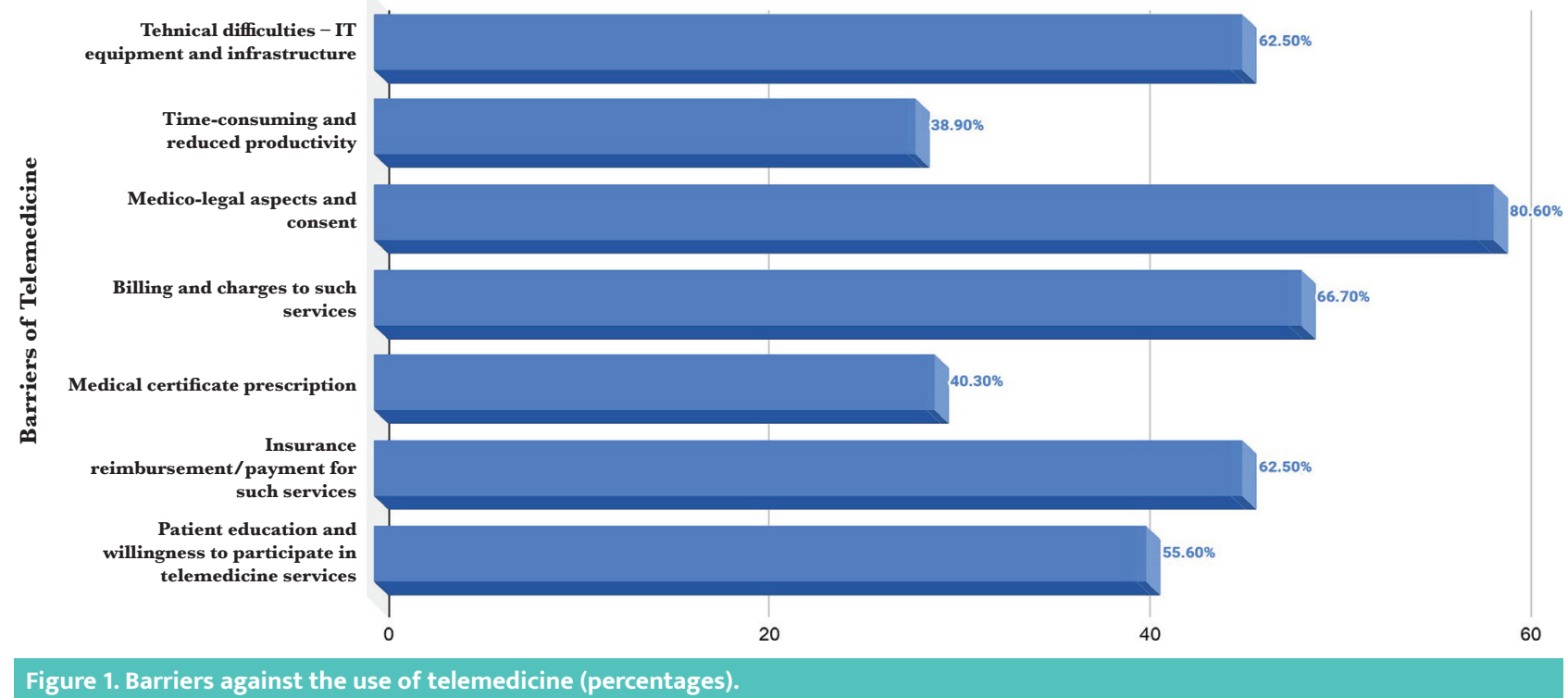




\section{JOURNAL of MEDICINE and LIFE}

There were multiple concerns regarding the implementation of telemedicine and why it would benefit a minority of patients in this study. Primarily, the doctors were concerned about the medico-legal, security and privacy implications of telemedicine $(80.6 \%)$. Medico-legally, doctors are at risk, as there is a lack of rules, legislation, and updated protocols for telemedicine, unlike its more traditional face-to-face counterpart [27]. For example, when a misdiagnosis occurs during a virtual consultation, the fault may lie with the technology, doctor, or patient. Therefore, the legal processes to overcome it are far more complicated than a similar error occurring during a face-to-face consultation where the law is standardized and universal.

The Malaysian Medical Council (MMC) advisory on telemedicine during the COVID-19 pandemic states that medical practitioners must possess adequate training, require valid informed consent, confirm the identity of patients, patient approval on other parties present and make sure that the technology used complies with legal requirements regarding privacy and security. However, the biggest drawback to the advisory was the requirement for doctors to reserve the practice of telemedicine solely for patients under their care. This may be a limitation of telemedicine in the COVID-19 era as it prevents doctors from conducting telemedicine consults on new patients who have no access to the hospital during the pandemic [28]. The Malaysian Code of Professional Conduct states that physical examination is mandatory for a patient consult. However, the advisory on telemedicine has given a leeway for non-physical telemedicine applied during the pandemic and not after.

The second concern was reimbursement or bill payments for telemedicine services. Questions arise if consultation fees via telemedicine should be based on current guidelines of face-face consultations or if they should be reduced as no physical examination is performed. However, this does not resolve the fact that the doctor is still consulting, interpreting results, and providing professional advice during telemedicine via audio-only phone calls, video calls, text chat, or e-mails.

Currently, in Malaysia, online health providers cite a fee of about 20 Ringgit Malaysia (RM) (4.70 USD) for a consult with a general practitioner and $40 \mathrm{RM}(9.40 \mathrm{USD})$ for a consult with a specialist [29]. These charges are much lower than a face-to-face consultation at private clinics or hospitals. Hence, they may not be financially viable given the substantial initial investment of telemedicine. This could negatively affect the income of clinicians if traditional fee-for-service payment methods continue to be followed.

The third concern in implementing telemedicine was the technical difficulties. Doctors felt that the current environment lacked the adequate infrastructure for telemedicine (62.5\%). This included Internet bandwidth, network issues, proper video conferencing applications, and reliable data storage. This corresponded to a study in Saudi Arabia where only 33.3\% of clinicians were actually implementing telemedicine in hospitals that adopted it. Reasons cited were technical issues, insufficient training for doctors, and poor response from patients who preferred face-to-face consultations [18]. In terms of security and privacy issues, doctors were skeptical that the current systems available were safe and secured (i.e., not easily hacked or spied on). During the COVID-19 pandemic, there have been issues regarding patient privacy intrusions through the use of tools such as the Zoom Communication Inc. application for video conferencing [30]. These tools are simple, inexpensive, and easy to use by healthcare providers and patients alike. However, they lead to issues such as hacking intrusions and non-secure storage of video data. In the USA, doctors risk facing lawsuits or state actions for patient privacy violations despite acting in "good faith" to provide telemedicine services during the COVID-19 pandemic [30]. Therefore the concern for data privacy and security is critical.

The other concerns include patient education and willingness to participate (55.6\%). This agreed with a recent study conducted in an urban city in Malaysia where less than half of its 4504 respondents found that the role of the Internet or a mobile health application was beneficial to them [31]. The authors indicated that this was due to most respondents having limited knowledge regarding the use of online health applications and the cost of embracing such technology [31]. Even in the neighboring country of Singapore, an urban center with one of the highest penetration of information technology globally, a recent study found that only $52.5 \%$ of their population was willing to use telemedicine [32]. Deterrents to telemedicine included age, ethnicity, patients' beliefs, cost and privacy [32].

Finally, doctors were also concerned over the legality of online medical certificate (MC) prescription (40.4\%). This concern stems from an age-old tradition where MCs were required to be stamped with a doctor's Medical Council stamp in order for employers to verify its validity and authenticity [33]. In our study, the majority of doctors were comfortable with online MC prescriptions.

\section{Limitations}

The response rate of $41.7 \%$ was considered low, but it would be understandable as many are struggling to cope with the unprecedented changes in their daily practice. This study had participants mainly from a private healthcare system where most doctors were senior consultants, with many having above 20 years of experience. It is possible that the sampling method may have led to a self-selecting bias, in which doctors who were particularly willing and able to practice telemedicine did not participate. This study only targets a niche population in urban private institutions covering four neighboring states in West Malaysia. An inclusive study should include the states of East Malaysia (i.e., Sabah and Sarawak) with a larger rural community and doctors from public hospitals where healthcare accessibility and patient congestion represent an issue.

This study had participants mainly from disciplines that require an in-person physical examination and may be underrepresented by those from disciplines where telemedicine is more suited. 


\section{JOURNAL of MEDICINE and LIFE}

\section{Recommendations}

According to Bashshur et al., the success of telemedicine rests on the three pillars of care: improved access, enhanced quality, and cost containment [34]. Therefore, firstly, the adoption of telemedicine has to be a government initiative. This will allow for standardization of guidelines and wider access to the public [35]. The benefits of a centralized system with government support have been shown briefly during this COVID-19 pandemic through the initiation of online tracking applications (i.e., MySejahtera, Selangkah) [36]. Although in their infancy, these applications have been able to rapidly attain widespread use throughout the country through extensive media coverage and issuance of incentives for downloading this application [36]. The benefits of these government-supported telemedicine initiatives have seen similar responses in other countries such as China, Taiwan, Korea, and Singapore [37].

Secondly, telemedicine needs to be financially viable for both healthcare providers and the public. Policy-makers and insurance providers should provide clarity on reimbursements on the various telemedicine encounters and pivot away from the traditional payment models [27]. This has been observed in multiple countries (e.g., United Kingdom, Germany, Sweden, France, Australia) since the start of the COVID-19 pandemic [38, 39]. In those countries, government and insurance companies have moved with an uncharacteristic speed to have various teleconsultations covered.

Thirdly, education initiatives would be needed for both clinicians and the public. As for clinicians, they should be informed about developing legislation and regulatory developments in telemedicine through conferences and seminars [24]. For the public, there needs to be more dissemination of information from healthcare providers, schools, and professional associations regarding the healthcare resources and support available through telemedicine.

Lastly, this study provides an insight into the perception of telemedicine amongst medical practitioners in the region prior to and during COVID-19. The recommendations will serve as an implementation guide for countries whose regions had limited use of telemedicine prior to the COVID-19 outbreak.

\section{CONCLUSION}

This study has shown that female doctors and physicians have a more positive outlook on telemedicine and are willing to participate when compared to male doctors and doctors from surgical specialties. However, regardless of gender, specialty, seniority, or loss of income, the majority of doctors perceived that telemedicine would only benefit up to $30 \%$ of their patients. The main barriers were medico-legal issues due to lack of proper legislation, reimbursement of services, technical difficulties, patient education and willingness to participate. The recommendations to improve the adoption of telemedicine include government engagement, fee standardization, and education initiatives. Therefore, although the COVID-19 pandemic appeared to improve the perception of telemedicine among clinicians and their willingness to adopt it, in reality, there are significant barriers that need to be resolved, and few doctors would truly implement telemedicine in Malaysia.

\section{ACKNOWLEDGMENTS}

\section{Ethical approval}

The approval for this study was obtained from the Ethics Committee of the KPJ Healthcare University College, Negeri Sembilan, Malaysia (approval ID: KPJUC/RMG/EG/2020/283).

\section{Consent to participate}

The participants entered the study voluntarily and their confidentiality was kept.

\section{Conflict of interest}

The authors declare that there is no conflict of interest.

\section{REFERENCES}

1. Malay Mail. Covid-19: Malaysia goes into nationwide pause from tomorrow and what we know so far. Press Release, 17 March, 2020.

2. Greenhalgh T, Wherton J, Shaw S, Morrison C. Video consultations for covid-19. BMJ. 2020;368:m998.

3. Zhou X, Snoswell CL, Harding LE, Bambling M, Edirippulige S, Bai X, et al. The Role of Telehealth in Reducing the Mental Health Burden from COVID-19. Telemed J E Health. 2020;26(4):377-9.
4. Tran BX, Hoang MT, Vo LH, Le HT, Nguyen TH, Vu GT, et al. Telemedicine in the COVID-19 Pandemic: Motivations for Integrated, Interconnected, and Community-Based Health Delivery in Resource-Scarce Settings? Front Psychiatry. 2020;11.

5. American Telemedicine Association: Telehealth basics. https://www.americantelemed.org/resource/why-telemedicine/ Accessed on 30 May 2020.

6. Boehm K, Ziewers S, Brandt MP, Sparwasser P, Haack M, Willems F, et al. Telemedicine Online Visits in Urology During the COVID-19 Pandemic-Potential, Risk Factors, and Patients' Perspective. Eur Urol. 2020.
7. Freeman MP. COVID-19 From a Psychiatry Perspective: Meeting the Challenges. J Clin Psychiatry. 2020;81(2).

8. Loeb AE, Rao SS, Ficke JR, Morris CD, Riley LH, $3^{\text {rd }}$, Levin AS. Departmental Experience and Lessons Learned With Accelerated Introduction of Telemedicine During the COVID-19 Crisis. J Am Acad Orthop Surg. 2020;28(11):e469-e76.

9. Pollock K, Setzen M, Svider PF. Embracing telemedicine into your otolaryngology practice amid the COVID-19 crisis: An invited commentary. Am J Otolaryngol [preprint]. 2020. 


\section{JOURNAL of MEDICINE and LIFE}

10. Saleem SM, Pasquale LR, Sidoti PA, Tsai JC. Virtual Ophthalmology: Telemedicine in a Covid-19 Era. Am J Ophthalmol. 2020.

11. Elkaddoum R, Haddad FG, Eid R, Kourie HR Telemedicine for cancer patients during COVID-19 pandemic: between threats and opportunities. Future Oncol [preprint]. 2020

12. Mann DM, Chen J, Chunara R, Testa PA, Nov O. COVID-19 transforms health care through

telemedicine: evidence from the field. J Am Med Inform Assoc [preprint]. 2020

13. CNBC. Demand for telemedicine has exploded in the UK as doctors adapt to the coronavirus crisis. Press Release, 9 April, 2020

14. Rodriguez Socarrás M, Loeb S, Teoh JY, Ribal MJ, Bloemberg J, Catto J, et al. Telemedicine and Smart Working: Recommendations of the European Association of Urology. Eur Urol [Epub ahead of print]. 2020.

15. Hu PJH, Chau PYK, Sheng ORL. Adoption of Telemedicine Technology by Health Care Organizations: An Exploratory Study. J ORGAN COMPUT ELECTRON COMME. 2002;12:197-221.

16. Ibrahim MIM, Palaian S. Evaluation of knowledge and perception of Malaysian health professionals abou telemedicine. J Clin Diagn Res. 2010;4:2052-7.

17. Gaggioli A, di Carlo S, Mantovani F, Castelnuovo Ga, Riva G. A Telemedicine Survey among Milan Doctors. Journal of Telemedicine and Telecare. 2005;1 1(1):29-34.

18. El-Mahalli AA, El-Khafif SH, Al-Qahtani MF. Successes and challenges in the implementation and application of telemedicine in the eastern province of Saudi Arabia. Perspect Health Inf Manag. 2012;9:1-27.

19. McCool RR, Davies L. Where Does Telemedicine Fit into Otolaryngology? An Assessment of Telemedicine Eligibility among Otolaryngology Diagnoses. Otolaryngol Head Neck Surg. 2018;158(4):641-4

20. Asiri A, Al Bishi S, Al Madani W, El Metwally A, Househ M. The Use of Telemedicine in Surgical Care: a Systematic Review. Acta Inform Med. 2018;26(3):201-6.
21. Ielpo B, Podda M, Pellino G, Pata F, Caruso R, Gravante $\mathrm{G}$, et al. Global attitudes in the management of acute appendicitis during COVID-19 pandemic: ACIE Appy Study. Br J Surg. 2020.

22. Di Saverio S, Pata F, Khan M, Ietto G, Zani E, Carcano G. Convert to open: the new paradigm for surgery during COVID-19? Br J Surg. 2020;107(7):e194.

23. Di Saverio S, Pata F, Gallo G, Carrano F, Scorza A, Sileri $\mathrm{P}$, et al. Coronavirus pandemic and colorectal surgery: practical advicebased on the Italian experience. Colorectal Dis. 2020;52(6):625-34.

24. Benítez CY, Ribeiro Jr MAF, Alexandrino H, Koleda P, Baptista SF, Azfar M, et al. International cooperation group of emergency surgery during the COVID-19 pandemic. Eur J Trauma Emerg Surg 2020.

25. Hao F, Tan W, Jiang L, Zhang L, Zhao X, Zou Y, et al. Do psychiatric patients experience more psychiatric symptom during COVID-19 pandemic and lockdown? A Case-Control Study with Service and Research Implications for Immunopsychiatry Brain Behav Immun. 2020;87:100-6.

26. Zhang MW, Ho RC. Moodle: The cost-effective solution for internet cognitive behavioral therapy (I-CBT) interventions. Technology and Health Care: Official Journal of the European Society for Engineering and Medicine. 2017;25(1):163-5.

27. Becker CD, Dandy K, Gaujean M, Fusaro M, Scurlock C. Legal Perspectives on Telemedicine Part 1: Legal and Regulatory Issues. Perm J. 2019;23.

28. Malaysian Medical Council. Advisory on Virtual Consultation (during the Covid19 pandemic). https://mmc.gov.my/wp-content/uploads/2020/04/MMC virtualconsultationADVISORY.pdf Accessed on 8 June 2020

29. The Edge Markets. Digital Health: Treating industry woes one issue at a time. Press Release, 22 March 2020.
30. Bloomberg Law. Doctors Using Zoom Face Security Scrutiny During Virus Press Release, 21 April 2020.

31. Lee JY, Wong CP, Lee SWH. m-Health views and perception among Malaysian: findings from a survey among individuals living in Selangor. mHealth. 2019;6(6).

32. Sin DYE, Guo X, Yong DWW, Qiu TY, Moey PTS, Falk MR, et al. Assessment of willingness to Telemonitoring interventions in patients with type 2 diabetes and/or hypertension in the public primary healthcare setting. BMC Medical Informatics and Decision Making. 2020;20(11).

33. Malay Mail. MCs must have MMC stamp, says ministry. Press Release, 20 May, 2014

34. Bashshur RL, Shannon G, Krupinski EA, Grigsby $\mathrm{J}$. Sustaining and realizing the promise of telemedicine Telemed J E Health. 2013; 19(5):339-45.

35. Zailani S, Gilani MS, Nikbin D, Iranmanesh M. Determinants of telemedicine acceptance in selected public hospitals in Malaysia: clinical perspective. J Med Syst. 2014;38(9):111

36. New Straits Times. Use MySejahtera app to find out Covid-19 cases within $1 \mathrm{~km}$ radius. Press Release, 28 May 2020.

37. Harvard Business Review. Health: How Digital Contact Tracing Slowed Covid-19 in East Asia. Press Release, 15 April 2020.

38. Sifted. Digital doctor demand goes through the roof. Press Release, 25 March 2020

39. Australian Government Department of Health: COVID-19 Temporary MBS Telehealth Services. http://www.mbsonline govau/internet/mbsonline/publishing 